\title{
Submarginal drumlin formation and late Holocene history of Fláajökull, southeast Iceland
}

\author{
Sverrir Aðalsteinn JÓNSSON, ${ }^{1}$ Ívar Örn BENEDIKTSSON, ${ }^{1}$ Ólafur INGÓLFSSON, ${ }^{1,2}$ \\ Anders SCHOMACKER, ${ }^{3}$ Helga Lucia BERGSDÓTTIR, ${ }^{1}$ William R. JACOBSON Jr., ${ }^{4}$ \\ Hans LINDERSON ${ }^{5}$ \\ ${ }^{1}$ Institute of Earth Sciences, University of Iceland, Sturlugata 7, IS-101 Reykjavík, Iceland \\ E-mail:saj7@hi.is \\ ${ }^{2}$ University Centre in Svalbard (UNIS), P.O. Box 156, N-9171 Longyearbyen, Norway \\ ${ }^{3}$ Department of Geology, UiT The Arctic University of Norway, Postboks 6050 Langnes, N-9037 Tromsø, Norway \\ ${ }^{4}$ University of Wisconsin-Milwaukee, P.O. Box 413, Lapham Hall 366, Milwaukee, WI 53201, USA \\ ${ }^{5}$ Department of Geology, Lund University, Sölvegatan 12, S-223 62 Lund, Sweden
}

\begin{abstract}
Fláajökull is a non-surging outlet glacier draining the south-eastern part of the Vatnajökull, southeast Iceland. Fláajökull was stationary or advanced slightly between 1966 and 1995 and formed a prominent end moraine. Glacial retreat since then has revealed a cluster of $\mathbf{1 5}$ drumlins. This study focuses on the morphology and sedimentology of the drumlins. They are 100-600 m long, 40-130 m wide, and have cores of glaciofluvial sediment or till. The drumlins are draped by $\sim 1 \mathrm{~m}$ thick, massive subglacial traction till. The glacier forefield is characterized by a number of arcuate and saw-tooth, terminal and recessional moraine ridges, overridden moraines with fluted surfaces, and glaciofluvial outwash. Some of the drumlins extend towards the 1995 end moraine but terminate abruptly at the moraine and are not observed in front of it. This suggests that they were formed sub-marginally during the 1966-1995 terminal position. The sedimentary structure of the drumlins is best explained by the sticky spot model. Dating and dendrochronological analyses of birch logs found on the surface of one of the drumlins indicate that the valley was forested about 2100 calendar year BP, after which the glacier started to reform, possibly due to an abrupt change in climate.
\end{abstract}

KEYWORDS: drumlins, glacial geology, glacial geomorphology, glacial sedimentology, glacial tills

\section{INTRODUCTION}

Drumlins are important landforms of many Pleistocene landscapes and, although they have been extensively studied, the exact nature of their formation is still enigmatic (Menzies, 1979; Patterson and Hooke, 1995; Clark and others, 2009). It is widely accepted that drumlins form beneath glaciers through ice/substrate interaction (Benn and Evans, 2006); i.e. through deposition, erosion, deformation or a combination of these processes. Drumlins are usually thought to have formed some distance behind the ice front. This is reflected in ice stream models (Stokes and Clark, 2001), in the active temperate glacial landsystem model by Evans and Twigg (2002), and has been suggested for well-studied drumlin fields, such as the Great Lakes region drumlin fields of North America (Kerr and Eyles, 2007; Maclachlan and Eyles, 2013).

Drumlins are not as common in the forefields of modern glaciers as in Pleistocene landscapes. Single drumlins or drumlins in small groups have been observed in modern glacial environments in Iceland (Krüger and Thomsen, 1984; Boulton, 1987; Kjær and others, 2003; Schomacker and others, 2006, 2012; Waller and others, 2008), Antarctica (Rabassa, 1987), Switzerland (van der Meer, 1983) and Alaska (Haselton, 1966). To date, however, the only modern drumlin field that has been described is at Múlajökull, Central Iceland (Johnson and others, 2010; Jónsson and others, 2014).

The Little Ice Age (LIA) in Iceland started about AD 1250 (Geirsdóttir and others, 2009) and peaked at the end of the 19th century. After a more or less continuous retreat from their LIA terminal positions during the most of the 20th century, most Icelandic outlet glaciers experienced a minor re-advance during the last quarter of the 20th century that generally culminated about 1995 (Sigurdsson, 2003). During the following accelerated retreat (Sigurdsson, 2013), drumlins have been revealed at the margins of some Icelandic glaciers, including Múlajökull (Johnson and others, 2010; Jónsson and others, 2014), Sólheimajökull (Schomacker and others, 2012; Slomka and Eyles, 2015), Breiðamerkurjökull (Evans and Twigg, 2002), Sléttjökull (Kjær and others, 2003) and Skeiðarárjökull (Waller and others, 2008; Baltru`nas and others, 2014).

At Fláajökull (Fig. 1), an outlet glacier from Vatnajökull, southeast Iceland, a cluster of 15 drumlins has been exposed following a retreat of the glacier from a large end moraine formed in 1995 (termed the 1995 end moraine in this paper). Fláajökull is a non-surging glacier, and like all Icelandic outlet glaciers considered to be a temperate glacier (Björnsson and Pálsson, 2008). We describe Fláajökull with reference to the active temperate glacier landsystem model of Evans and Twigg (2002) and Evans and others (1999), and in line with the approach of Evans and others (2015). According to this model, the forefield of temperate outlet glaciers is divided into three depositional domains: (a) areas of extensive, low amplitude marginal dump, push and squeeze moraines derived largely from material on the glacier foreland and often recording annual recession of active ice, (b) glaciofluvial landforms and (c) 

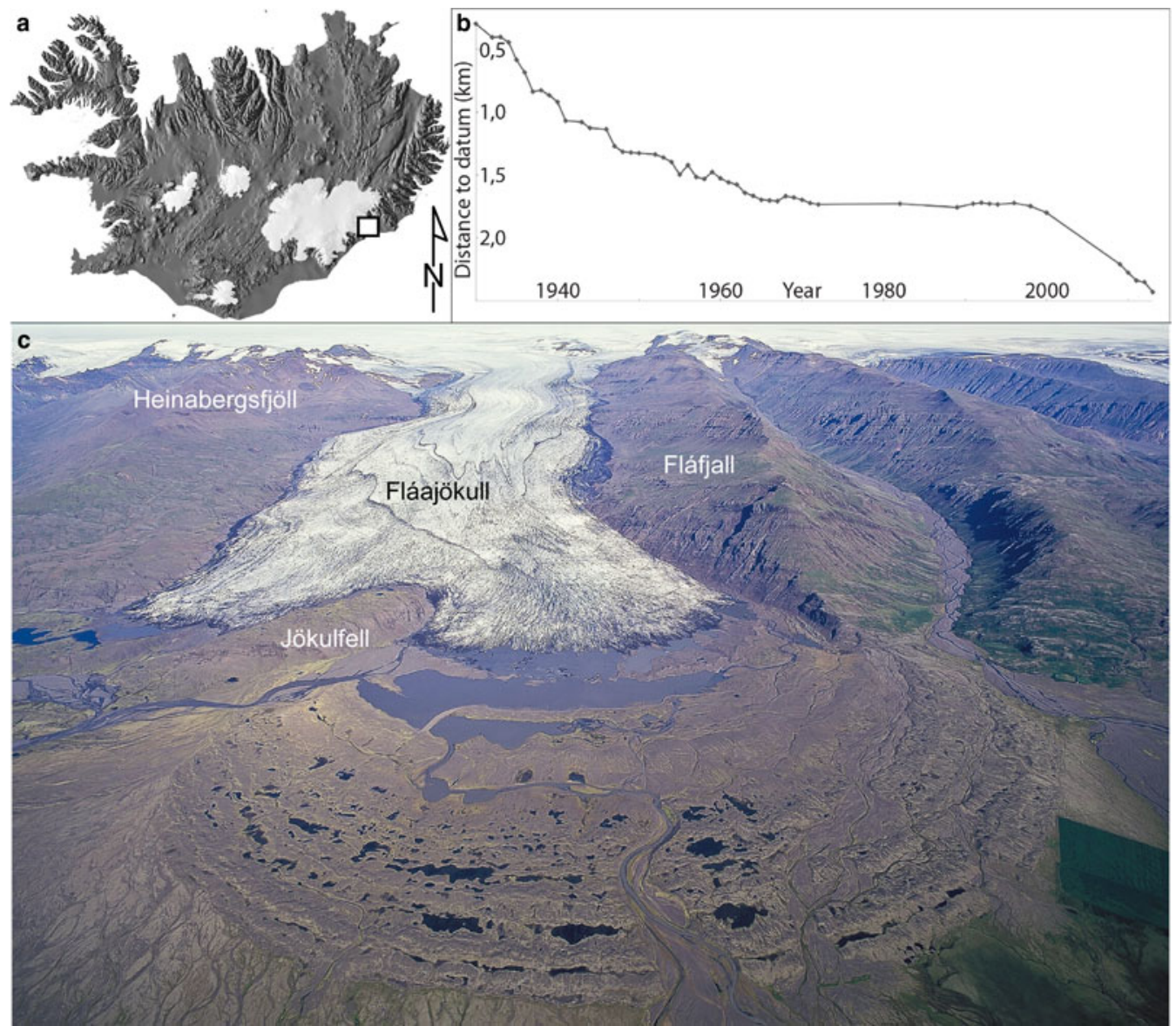

Fig. 1. (a) Location of Fláajökull (square) at the south-eastern margin of the Vatnajökull ice cap. (b) Variations of the glacier snout since 1930 (data from the Icelandic Glaciological Society at spordakost.jorfi.is). Note the still-stand and minor re-advance from 1966 to 1995. (c) A view of Fláajökull and its forefield from the southeast in 2007. Photograph courtesy: Snævarr Guðmundsson.

subglacial landforms such as flutes, drumlins and overridden end moraines.

We describe the morphology and sedimentology of the 15 drumlins within the recently exposed forefield and present a detailed geomorphological map in order to understand drumlin formation and the development of the active temperate landsystem at Fláajökull. In addition, a simplified Holocene glaciation history for Fláajökull is reconstructed based on previously published research and ${ }^{14} \mathrm{C}$ dates and dendrochronological analysis of birch logs sampled from the surface till of one of the drumlins.

\section{METHODS}

\section{Geomorphological mapping}

Mapping of landforms was undertaken using a combination of remote sensing and ground surveys (2012-14). An airborne $2.5 \mathrm{~m}$ LiDAR DEM covering the glacier and $\sim 2 \mathrm{~km}$ into the forefield was visualized as a terrain shade-relief model and used along with panchromatic aerial photographs, with $0.5 \mathrm{~m}$ pixel size, taken in 1982 and 1989 by Landmælingar Î́slands (National Land Survey) for mapping the forefield. The LiDAR data were recorded in 2010 by the Icelandic Meteorological Office and the Institute of Earth Sciences of the University of Iceland (Jóhannesson and others, 2013). All data were handled in ESRI ArcGIS 10 in the UTM/WGS84 reference system, and elevations are in meters above sea level.
Sediments and landforms were mostly mapped on the basis of the LiDAR DEM data but the orthophotographs were used both with the LiDAR and exclusively in the southeast part of the forefield, where LiDAR data were unavailable.

The length and width of the drumlins were measured in ArcGIS. The height of drumlins that are surrounded with water was measured from the water surface, which defines their basal plane height. Four drumlins were not fully exposed from under the ice margin and were not measured.

\section{Sedimentological logging}

Four stream-cut sections (A-D; see Fig. 6 for locations) in the drumlins were cleaned and logged following the data chart by Krüger and Kjær (1999). The lithology and principal sedimentological characteristics, i.e. grain size, sorting, clast content, matrix/clast relationship, and clast roundness of each unit were described in the field along with the nature of their basal contacts and their lateral extent. Interpretation of units was both done in the field and on the basis of anisotropy of magnetic susceptibility (AMS) measurements (see section Anisotropy of magnetic susceptibility).

\section{${ }^{14} \mathrm{C}$ dating of birch logs}

Three birch logs were discovered embedded in sediments on top of the northernmost drumlin. The dendrochronology of the logs was analysed at the Swedish National Laboratory for 


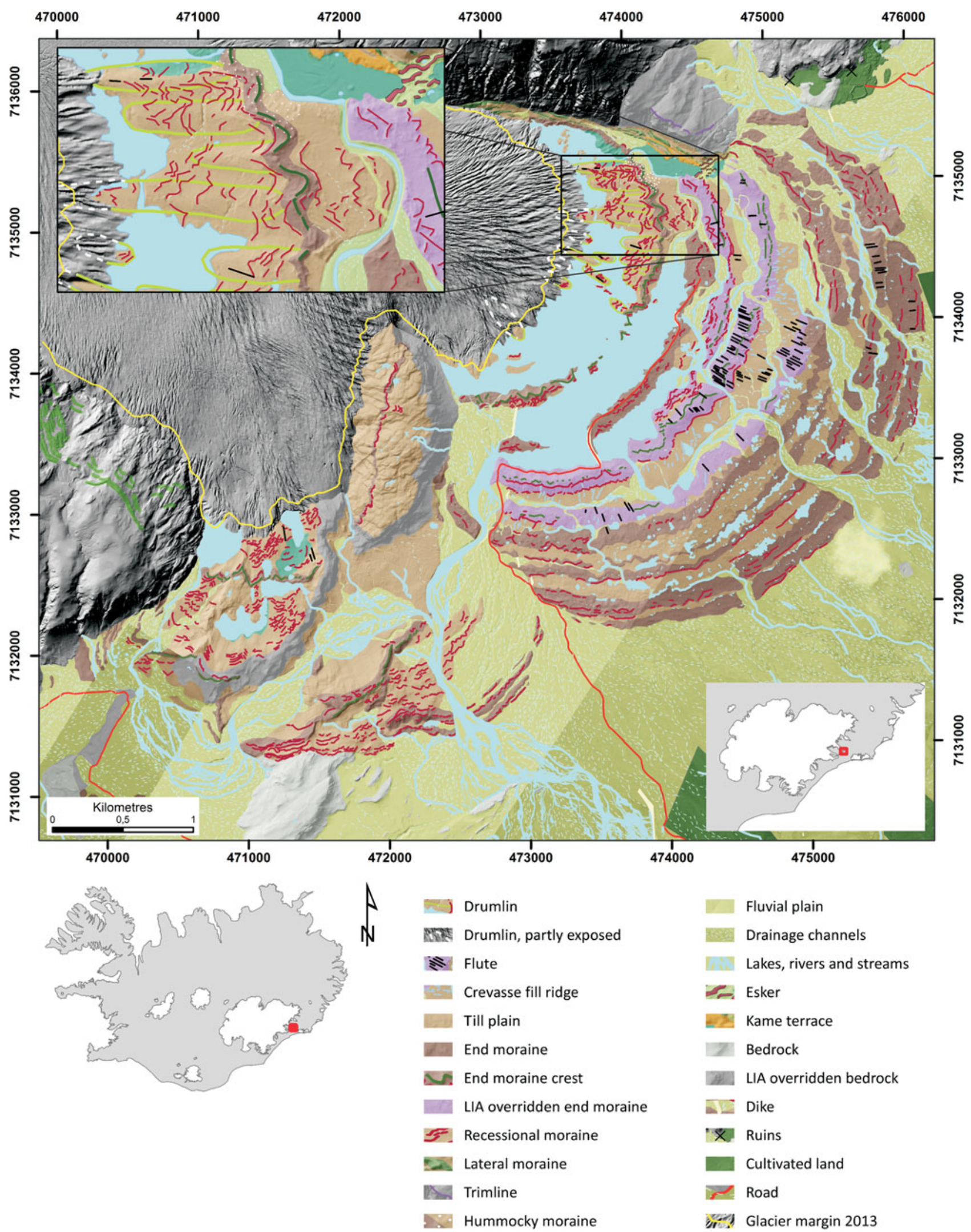

Fig. 2. Geomorphological map of the Fláajökull forefield. The map is based on aerial photographs recorded in 1989 and LiDAR data from 2010. Map projection and datum: UTM 28N, WGS 84. Scale 1:32 000 on large map and 1:13 000 on insert map.

Wood Anatomy and Dendrochronology, Lund University, and two of them were dated using Accelerator Mass Spectrometry at Lund University Radiocarbon Dating Laboratory. The dates were calibrated in OxCal 3.10 using the atmospheric data from Reimer and others (2013).

\section{Anisotropy of magnetic susceptibility}

We collected till specimens in the years 2012 and 2013 for (AMS measurements. These measurements were taken from three drumlin sections (A-C, see Fig. 6). A minimum of 25 plastic boxes $\left(8 \mathrm{~cm}^{3}\right)$ were used in the collection process for 

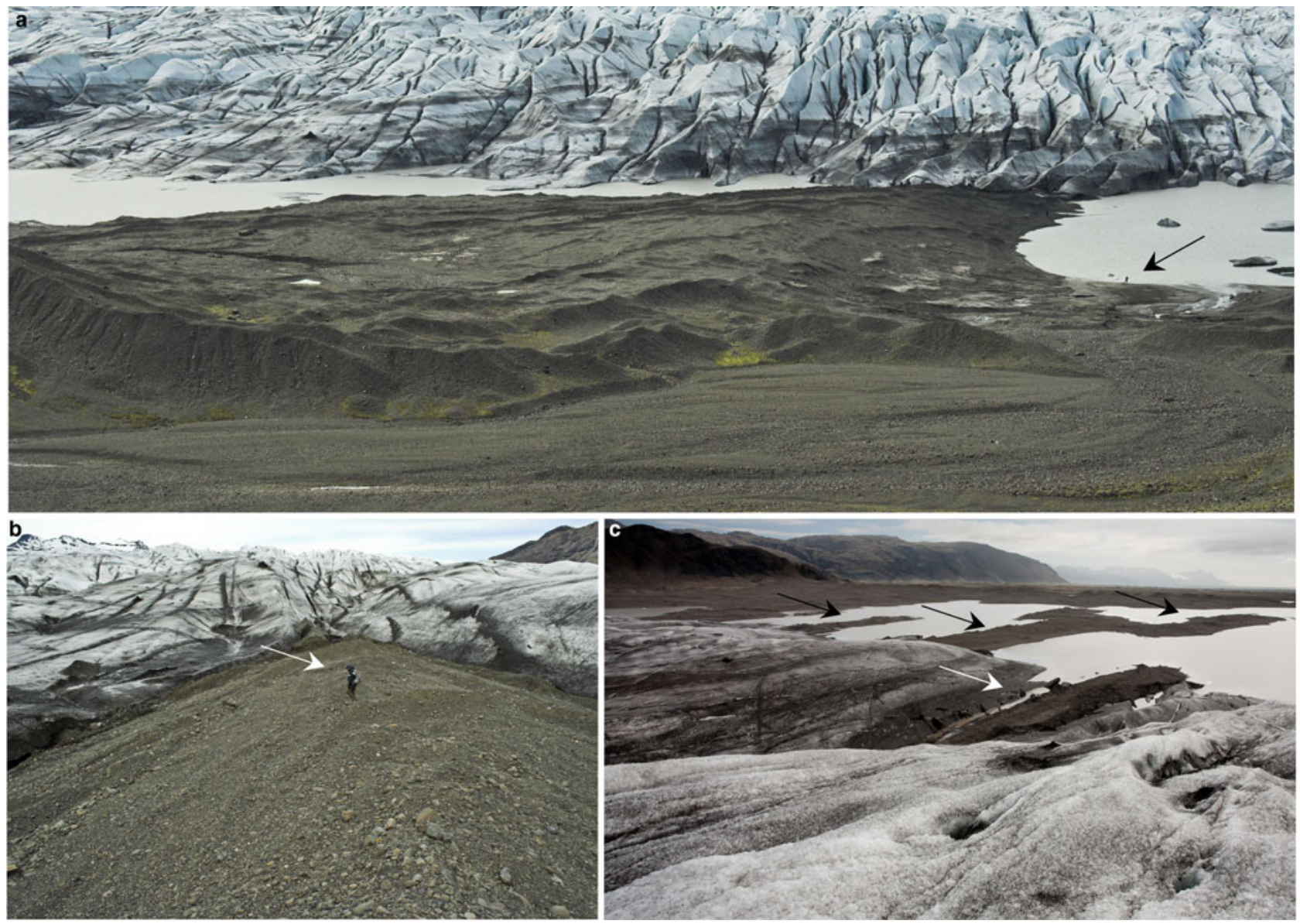

Fig. 3. (a) A prominent drumlin in the northernmost part of the forefield, with recessional moraines on top. The 1995 end moraine can be seen in the foreground. Note a person for scale (arrowed). (b) A view of a sharp-crested drumlin in 2011. Note a person for scale (arrowed). (c) View from the glacier towards north-east showing partly exposed drumlin (white arrow), and few other drumlins further away (black arrows) in 2012.

sampling. Principal directions of magnetic susceptibility $\left(k_{1}\right.$, $k_{2}$ and $k_{3}$ ) were measured using the AGICO MFK1-FA Fully Automatic KappaBridge to determine the three-dimensional (3-D) state of strain, which is visualized with a susceptibility ellipsoid (Jelínek and Kropáček, 1978). Furthermore, the ellipsoids are used to identify the 3 -D strain style, direction and magnitude of the microfabric (e.g. allows simple shear to be distinguished from pure shear) and therefore to infer patterns of till deformation. Perhaps more importantly, the magnetic fabric provides excellent spatial resolution because of its averaging effect of many magnetic grains rather than the orientation of a single grain.

In addition to the AMS measurements, we conducted high temperature susceptibility (HTS) and hysteresis experiments. These experiments were performed in order to determine the magnetic carrier and grain size. HTS experiments were evaluated on the fine-grained particles (clay and silt) that were $<65$ $\mu \mathrm{m}$. The unblocking temperature was used to identify the mineralogy and hysteresis loop parameters helped target the particle size. The magnetic fabric data were analysed using the procedure outlined by Mark (1973).

\section{REGIONAL SETTING AND GEOMORPHOLOGY}

\section{Fláajökull}

Fláajökull is $\sim 13 \mathrm{~km}$ long, non-surging outlet glacier draining the south-eastern part of the Vatnajökull ice cap (Björnsson,
2009; Fig. 1). The glacier flows to the southeast between Mount Fláfjall and Mount Heinabergsfjöll, and terminates on a flat sandur called Mýrar. The present glacier snout is split into two lobes by Mount Jökulfell. The small drumlin field is associated with the north-eastern lobe (Figs 1c and 2).

The ice front variations of Fláajökull have been recorded from 1894 and with some continuity from 1930 (Fig. 1b). There is, however, a gap in the records between 1972 and 1991 and again from 2000 to 2009. We added two ice front positions from aerial images taken in 1982 and 1989 to get a more complete record (Fig. 1b). The record shows a rapid retreat between about 1930 and 1942, and again after 1998, but a still-stand or even a minor re-advance between 1966 and 1995. After 1995 the Fláajökull ice margin has retreated rapidly and is now (2013) located $706 \mathrm{~m}$ inside the moraine.

According to radio echo soundings from year 2000, the glacier occupies a $60 \mathrm{~m}$ deep depression inside the present ice margin North of Mount Jökulfell (Fig. 1c). This depression gets gradually shallower towards the 1995 end moraine (Pálsson and Björnsson, 2000).

Direct velocity measurements of Fláajökull do not exist. However, a velocity of a few metres to a few tens of metres per year is presumed based on both measured and modelled velocities at the adjacent Hoffellsjökull glacier, which rests in a similar topographic and climatic setting just $11 \mathrm{~km}$ east of Fláajökull (Aðalgeirsdóttir and others, 2011) (Figs 2 and 3). 

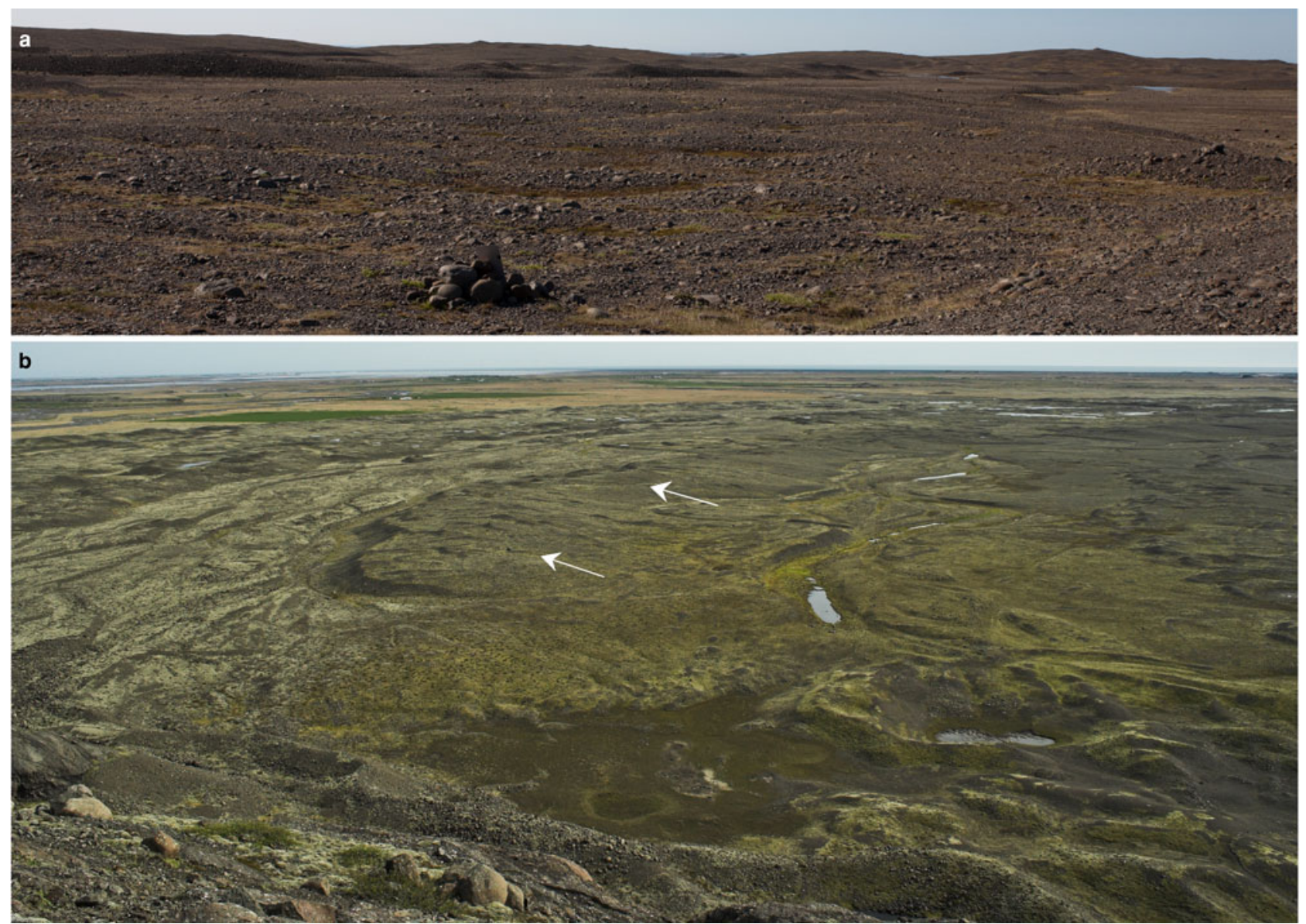

Fig. 4. (a) An overridden end moraine in the central forefield. Ice flow was away from the viewer. (b) The same overridden end moraine seen from above indicated with white arrows. The distal part of the moraine has been subject to glaciofluvial erosion. Ice flow was from right to left.

\section{Geomorphology of the forefield}

The landforms at Fláajökull are divided into four groups based on the glacial environment in which they are formed, i.e. subglacial, ice-marginal, supraglacial and glaciofluvial. Subglacial sediments and landforms are common in the forefield of Fláajökull. About half of the forefield is classified as a subglacial till plain (Fig. 2). The till plain is generally fluted with the most prominent flutes occurring on overridden, drumlinized end moraines, such as the one located $\sim 1.3 \mathrm{~km}$ from the ice front (Figs 2 and 4), (Evans and others, 2015). The flutes range between 1 and $90 \mathrm{~m}$ in length and $\sim 0.5$ and $1.5 \mathrm{~m}$ in width. More flutes than indicated in Figure 2 were observed in the field but were not mapped because of their small size or low resolution of the LiDAR image and/or aerial photographs. In addition to the flutes, we have mapped 15 drumlins, which are described in more detail in the section Drumlin Morphology and Sedimentology. Evans and others (2015) described a number of crevasse fill ridges but most of these ridges are interpreted as recessional moraines in the present study.

Ice-marginal landforms are widespread at Fláajökull. Multiple arcuate (dark brown in Fig. 2) and saw-tooth (red in Fig. 2; Burki and others, 2009) moraine ridges can be found in the forefield (Figs 2 and 6). The outermost terminal moraine is from the LIA maximum in 1894 (Hannesdóttir and others, 2014) and the innermost one from the re-advance that terminated in 1995. This moraine is $\sim 30 \mathrm{~m}$ wide and 10-25 $\mathrm{m}$ high above the surroundings, and conspicuous in the proximal part of the forefield, which probably owes to the fact that the ice margin was stationary around this position for a long time, supplying large amounts of sediment for moraine buildup (Fig. 5c).

There are a number of smaller recessional moraines in the forefield, formed during minor late winter/early spring readvances. These moraines are best preserved in the area inside the 1995 end moraine (Figs 2 and 5a). The recessional moraines are continuous for only short distances with individual segments ranging from a few meters to a few tens of meters in length and displaying a saw-tooth pattern. They are usually $\sim 1.5 \mathrm{~m}$ wide and $0.5-1 \mathrm{~m}$ high and consist most commonly of till.

Supraglacial landforms are rare at Fláajökull. However, surface fractures were observed within the hummocky moraine on the proximal slope of the 1995 end moraine (Fig. 2), indicating melting of buried ice.

Glaciofluvial sediments (sand and gravel) and landforms (drainage channels, sandur plains) from various meltwater outlets are conspicuous in the Fláajökull forefield (Fig. 2). The river Hólmsá drains Fláajökull and runs towards south, just east of Mount Jökulfell (Figs 1, 2 and 6), leaving behind a braided sandur. Fluvial plains and drainage channels are most extensive close to the present day Hólmsá outlet. In the northern part of the forefield, channels from former outlets close to Fláfell are inactive because of the retreat of the glacier and damming of river outlets. 

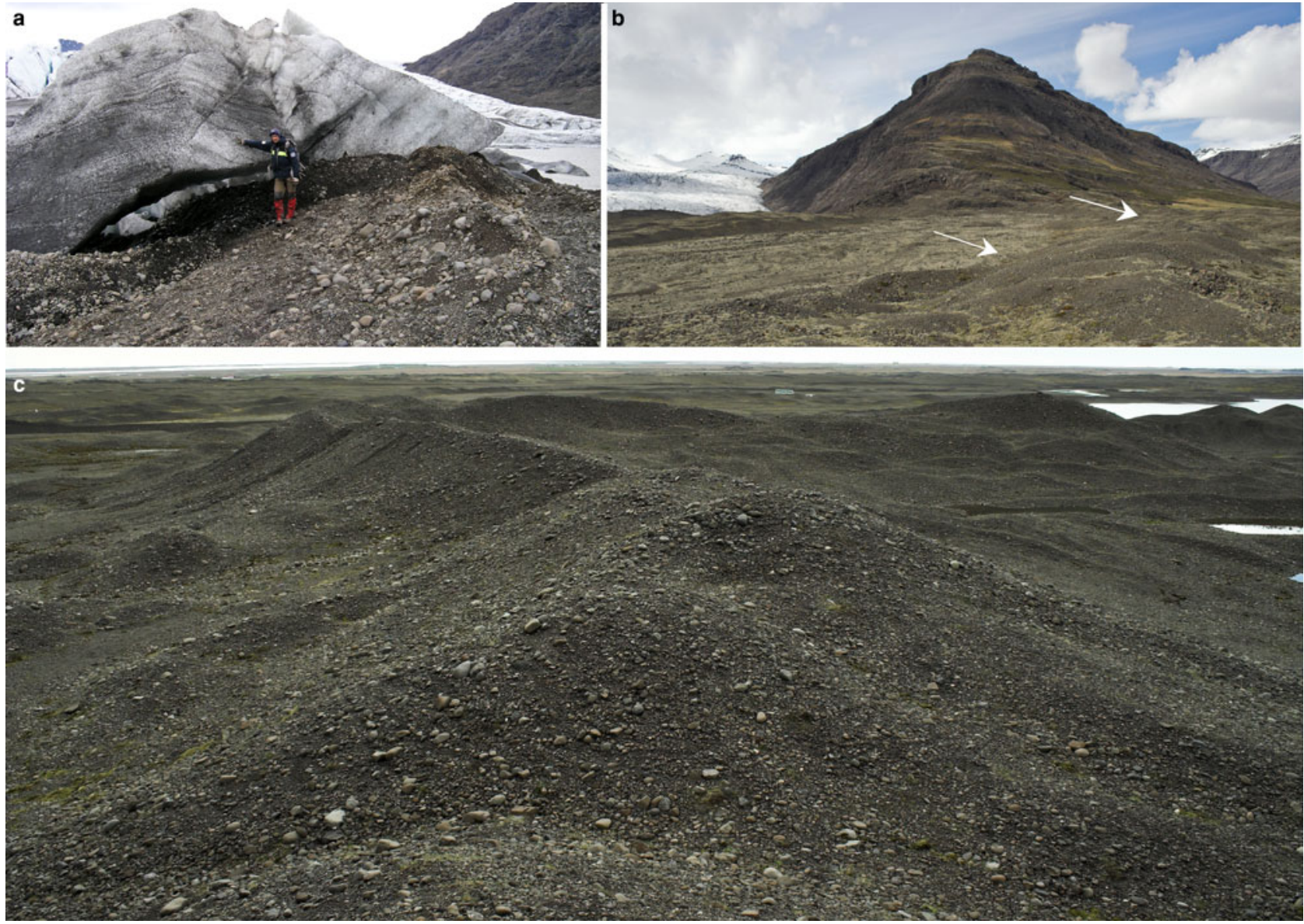

Fig. 5. (a) A recessional moraine forming at the ice front in the spring of 2010. Person for scale. (b) An old end moraine in the forefield of Fláajökull (arrowed). The width of the moraine is $\sim 30 \mathrm{~m}$. (c) View to the west along the crest of the 1995 end moraine. Note the sawtooth shape of the moraine. Ice flow was from right to left.

\section{DRUMLIN MORPHOLOGY AND SEDIMENTOLOGY}

\section{Size and morphology}

We mapped 15 drumlins at Fláajökull, four of which are only partly exposed and their exact size is thus not known (Fig. 6). The size of the fully exposed drumlins varies greatly. In the northern part, four large drumlins occur (numbered 1-4 in Fig. 6), ranging from 430 to $580 \mathrm{~m}$ in length, $115-130 \mathrm{~m}$ in width, and 8-13 $\mathrm{m}$ in height above the surrounding water table (Figs 2, 3a and 6), and with an elongation ratio of 2.4-4.8. All these drumlins extend towards the 1995 end moraine but not beyond it. This is most obvious at drumlin 3 , which is parabolic in shape at the down-glacier end (Fig. 6). Further south, there are four more drumlins (drumlins 5-8 in Fig. 6), extending to the 1995 end moraine. These drumlins are $120-210 \mathrm{~m}$ in length, $40-110 \mathrm{~m}$ in width and 3-8 $\mathrm{m}$ high, with an elongation ratio of 1.4-3.

Closer to the ice, three spindle shaped drumlins have completely emerged from the ice (drumlins 9-11 in Figs 3c and 6). These drumlins are located in a proglacial lake that is dammed by man-made dikes but also represents the down-glacier end of the subglacial overdeepening. Because these drumlins are partly under water, their full size could not be determined. Even when this is taken into account it seems clear that they are considerably smaller than the drumlins further north, all being $\sim 50 \mathrm{~m}$ wide and ranging in length from $\sim 160$ to 280 $\mathrm{m}$, giving an elongation ratio between 3.2 and 4.7.

Four more drumlins are currently emerging from the ice margin and have not been completely exposed (drumlins
12-15 in Figs 2 and 6). Their size is therefore not known but three of them seem to be relatively small while the one furthest south appears to be larger according to Figures 2 and 6.

The geometry and elongation ratio of the fully exposed drumlins, number $1-11$, is summarized in Table 1.

\section{Stratigraphy and sedimentology}

The stratigraphy and sedimentology of the drumlins was investigated in four excavated sections (A-D; see Fig. 6). The sections are located in three large drumlins in the northern part of the forefield and oriented perpendicular to the long axis of the drumlins. Section $A$ is located in the proximal end of drumlin 1 (Fig. 7a), section B (Fig. 9a) is in the centre of drumlin 2 (Fig. 9a), and sections $C$ and $D$ are located within drumlin 4, with section $C$ in the proximal part and section $D$ in the distal part (Figs 9c and 11).

Section A: Section $\mathrm{A}$ is located at the proximal end of drumlin 1 (Fig. 6). The section is $4.2 \mathrm{~m}$ high and consists of two stratigraphic units (Figs 7 and 9a). The lower unit, A-1, comprises massive, rounded gravel that is at least $4 \mathrm{~m}$ thick with its lower contact being unexposed (Fig. 8). The upper unit, A-2, is, at the macroscale, a massive, matrix-supported diamict that has silty-sandy matrix and is unconsolidated (easy to excavate). The unit is rich in subrounded to subangular clasts, typically ranging from $2-50 \mathrm{~cm}$ in diameter. The unit is $\sim 0.6 \mathrm{~m}$ thick but the thickness varies laterally between 0.3 and $0.8 \mathrm{~m}$. The contact with the underlying gravel is sharp. 


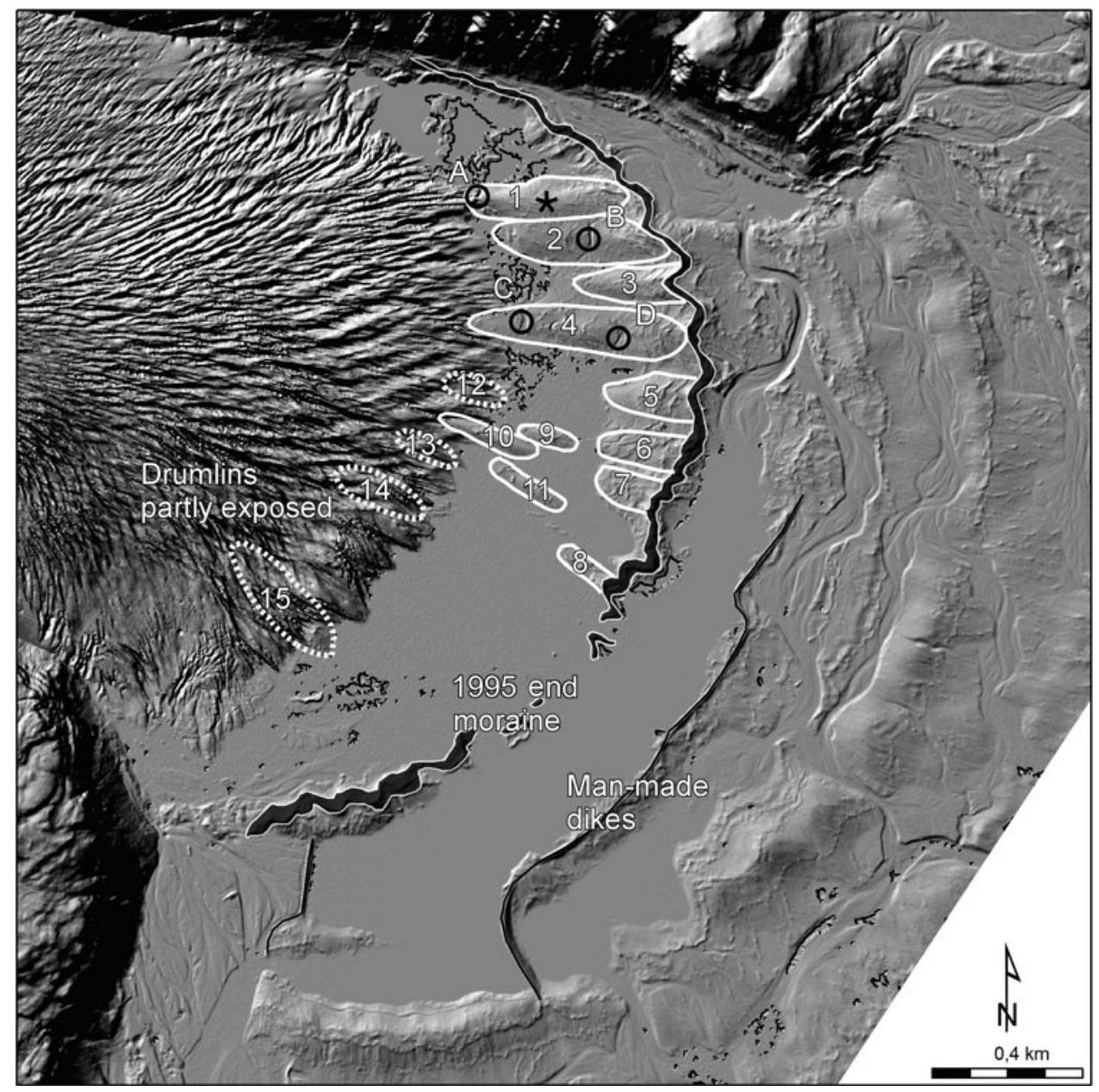

Fig. 6. A LiDAR hillshade model from 2010 showing the ice margin and the drumlins (numbered 1-15). Sections A-D are marked with black circles. Fully exposed drumlins are shown with white outlines, partly exposed drumlins, which were mapped on a 2014 satellite image, with dashed white outlines. The 1995 end moraine is black with white outlines. Man-made levees and dikes are marked with black lines. The asterisk marks the location of the birch logs found in the surface deposits at drumlin 1.

The surface is covered with a clast pavement. The AMS microfabric shows significant clustering of the $k 1, k 2$ and $k 3$ susceptibilities, with a shallow dip of $k 1$. This indicates a till shearing direction toward the southeast roughly parallel to the drumlins long axis ( $k 1 \mathrm{up}$-glacier plunge of $11^{\circ}$ ) with an approximately horizontal shear plane (defined by $k 2$ susceptibilities). The gravel is interpreted as proglacial outwash and the surface

Table 1. The length, width, height and elongation ratio of the fully exposed drumlins. The drumlin numbers refer to Figure 6

\begin{tabular}{|c|c|c|c|c|}
\hline Drumlin no. & $\begin{array}{c}\text { Length } \\
\mathrm{m}\end{array}$ & $\begin{array}{c}\text { Width } \\
\mathrm{m}\end{array}$ & $\begin{array}{c}\text { Height } \\
\text { m }\end{array}$ & Elongation ratio \\
\hline 1 & 430 & 115 & 12 & 3.7 \\
\hline 2 & 470 & 130 & 10 & 3.6 \\
\hline 3 & 240 & 100 & 13 & 2.4 \\
\hline 4 & 580 & 120 & 8 & 4.8 \\
\hline 5 & 210 & 110 & 8 & 1.9 \\
\hline 6 & 210 & 90 & 8 & 2.3 \\
\hline 7 & 150 & 110 & 8 & 1.4 \\
\hline 8 & 120 & 40 & 3 & 3 \\
\hline 9 & 160 & 50 & 3 & 3.2 \\
\hline 10 & 280 & 60 & 4 & 4.7 \\
\hline 11 & 220 & 50 & 3 & 4.4 \\
\hline
\end{tabular}

diamict as subglacial traction till (Table 1, Fig. 8; Evans and Benn, 2004; Evans and others, 2006, 2015).

Section B: Section B is located in the centre of drumlin 2 (Fig. 6). The section is $3.2 \mathrm{~m}$ high and consists of two till units (Fig. 10). The lower unit, B-1, is a diamict that is at least $2 \mathrm{~m}$ thick but its base is unexposed. At the macroscale, the diamict is massive, matrix-supported with sandy-gravelly matrix. It is rich in clasts that are up to $40 \mathrm{~cm}$ in diameter and mainly subangular to subrounded. Unit B-1 is unconsolidated and easy to excavate. The upper unit, B-2, is generally $\sim 1 \mathrm{~m}$ thick diamict but the thickness varies between 0.4 and $1.2 \mathrm{~m}$ with the lower boundary being gradational. At the macroscale, the diamict is massive, matrix-supported with silty-sandy matrix and moderately clast rich, with clasts being mainly subrounded to subangular and up to $\sim 30 \mathrm{~cm}$ in diameter. The diamict is poorly consolidated and easy to excavate and the surface is covered with a clast pavement. The AMS microfabric illustrates a girdle distribution of $k 1$ and $k 2$ susceptibilities with an average $k 3$ plunge of $54^{\circ}$ defining the pole to the shear plane ( $k 1-k 2$ plane). The mean $k 1$ susceptibility orientation plunges $11^{\circ}$ up-glacier, which is approximately parallel to the shearing direction and drumlin long axis. The lower unit, B-1, is interpreted as a subglacial traction till (Evans and others, 2006, 2015). The upper unit, B-2, is expressed in a recessional push moraine at this site (Krüger, 1995). However, it has similar characteristics as unit B-1 below and was thus probably initially 

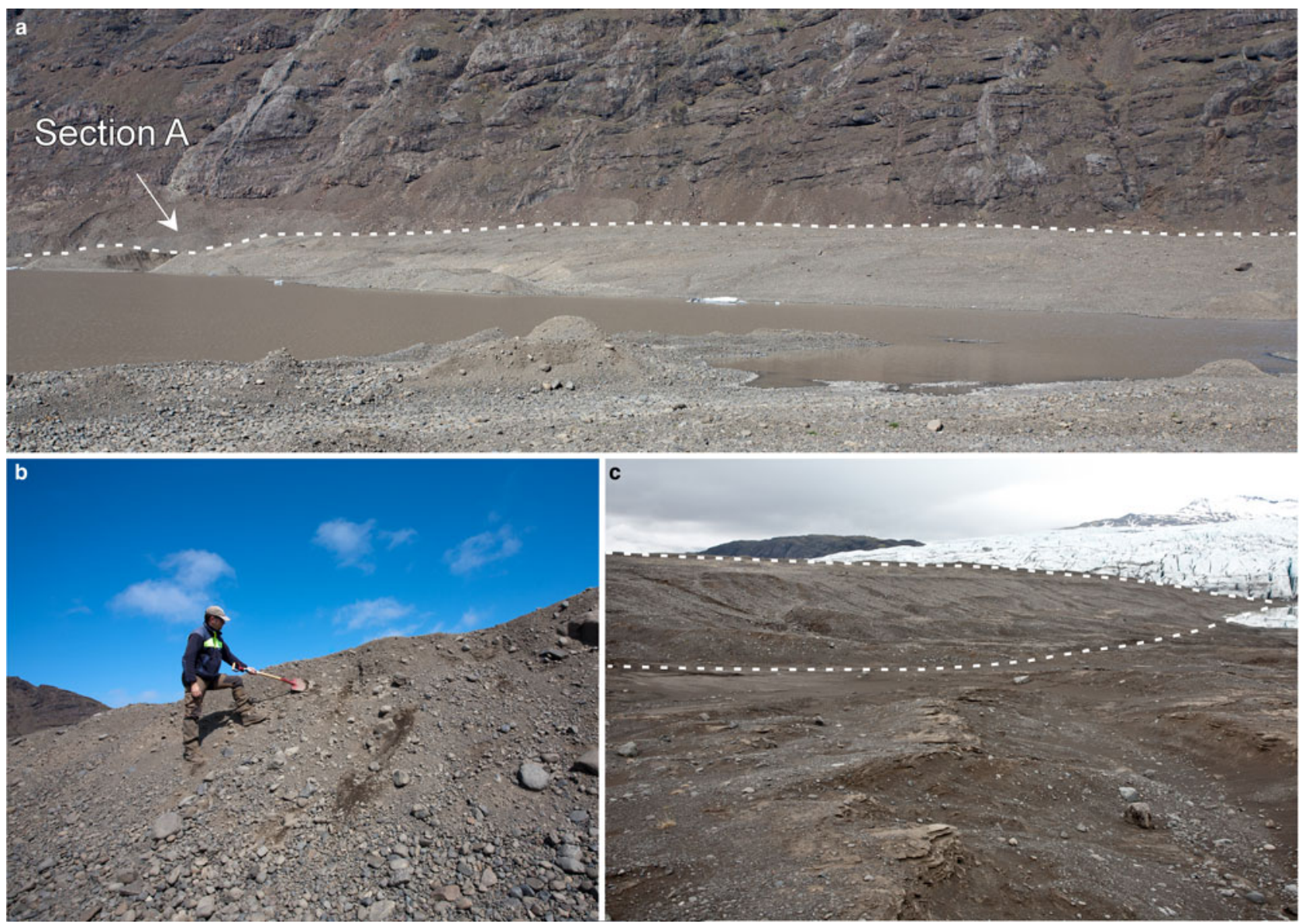

Fig. 7. (a) A view from the south toward the northernmost drumlin, location of section A is indicated. (b) The top of section A. The spade is pointed at the lower boundary of the top till. (c) The northernmost drumlin in the field, view from east. Section A (not visible) is located in the far end of the drumlin. The drumlin is $\sim 13 \mathrm{~m}$ high.

deposited as a subglacial traction till that subsequently got pushed by the ice margin during a recent late winter/early spring re-advance (Krüger, 1995) (Figs 9 and 10).

Section C: Section C is located in the proximal end of drumlin 4 (Fig. 6). The section is $2.8 \mathrm{~m}$ high and shows two units (Fig. 11). The lower unit, C-1, comprises a massive, coarse gravel with an exposed thickness of over $2 \mathrm{~m}$. The upper unit, C-2, is a diamict that is at the macroscale massive, matrix-supported with silty-sandy matrix, rich in 5-40 cm large, subangular to subrounded clasts and easy to excavate. The surface is covered with a clast pavement. The diamict is up to $0.7 \mathrm{~m}$ thick and the lower boundary is sharp. Section $\mathrm{C}$, shows an AMS fabric broadly similar to section $\mathrm{B}$; however, $k 1$ axes cluster at $77^{\circ}$ and gently plunge at $19^{\circ}$ up-glacier and $k 3$ axes cluster at $190^{\circ}$ and plunge moderately at $73^{\circ}$, perpendicular to the shear plane. Shearing is subparallel to the glacier flow direction toward the southeast. The lower unit was interpreted as glaciofluvial outwash and the upper unit as subglacial traction till (Evans and Benn, 2004; Evans and others, 2006, 2015).

Section D: Section D is located in the distal end of the same drumlin as section C, i.e. drumlin 4 (Fig. 6). The section is 2.1 $\mathrm{m}$ high and consists of two units (Figs 12 and 13). The lower unit, D-1, is over $1 \mathrm{~m}$ thick diamict with its lower boundary unexposed. At the macroscale, the diamict is massive, matrix-supported with sandy-gravelly matrix and rich in $<30 \mathrm{~cm}$ large clasts. The diamict is easy to excavate. The upper unit, D-2, is an easily excavated diamict, at the macroscale massive, matrix-supported with silty-sandy matrix and moderate content of up to $20 \mathrm{~cm}$ large clasts. The diamict is typically $\sim 1 \mathrm{~m}$ thick but the thickness is variable, with a sharp conformable lower contact to D-1. The surface is covered with clast pavement and there is a sand lens in the top of the unit. This AMS fabric site displays significant clustering of $k 1, k 2$ and $k 3$ susceptibilities, as also revealed from section A. The mean $k 1$ susceptibility axes cluster at $002^{\circ}$ and plunge $1^{\circ}$ up-glacier, $k 2$ susceptibilities cluster at $093^{\circ}$ approximately normal to the $k 1$ clusters and $k 3$ clusters are oriented at $183^{\circ}$ and steeply plunge at $85^{\circ}$. The longitudinal flow plane ( $k 1-k 3$ plane) is approximately parallel to the drumlin long axis. Both units, D-1 and D-2, are interpreted as subglacial traction tills and the sand lens at the top as a small channel fill (Evans and others, 2006, 2015).

\section{CHRONOLOGY}

About 70 m southwest of section A (Fig. 6), compact, greyish to bluish sediment was observed at the surface of drumlin 1 down to $\sim 10-20 \mathrm{~cm}$ depth. We interpret this sediment to be peat/palaeosol originating in the valley, now occupied by the glacier. The sediment has been deformed and dislocated by the advancing glacier and finally deposited on top of the drumlin. The sediment contains birch logs that are 15-60 cm long and 10-20 cm in diameter (Fig. 14). Two of the birch logs were sampled for ${ }^{14} \mathrm{C}$ dating. The first sample, LuS 10801, gave ${ }^{14} \mathrm{C}$ age of $2165 \pm 35 \mathrm{BP}$ and calibrated age range with 95,4\% probability of 2310-2055 BP. Analysis of the shape of this specimen and its tree rings 


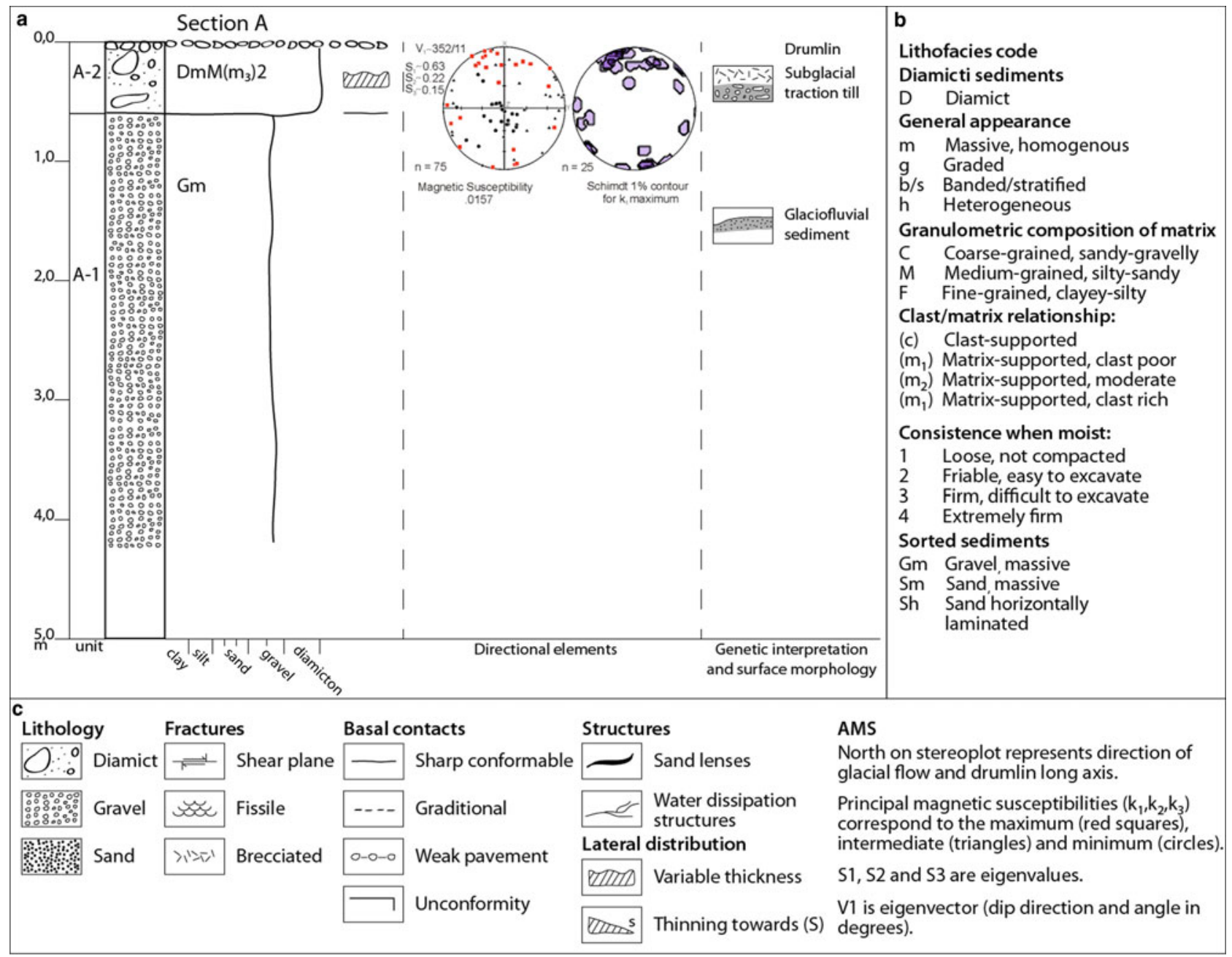

Fig. 8. (a) Sedimentological log from section A. (b-c) Explanations of lithofacies codes and symbols used in this and other logs in Figures 10,11 and 13.

indicates that this tree was $20-30 \mathrm{~cm}$ in diameter and rather fast growing, suggesting relatively warm conditions (Fig. 14a). The second sample, LuS 10802, gave ${ }^{14} \mathrm{C}$ age of $2105 \pm 35 \mathrm{BP}$ and calibrated age range with $93,1 \%$ probability of 2155-1990 BP. Dendrochronological analysis indicates that the sample is from a 25-40 a old tree with dense tree rings, suggesting colder growing conditions (Fig. 14b). The third sample, ISO00 (Fig. 14c), was not dated but allowed for a more accurate dendrochronological analysis showing 84 tree rings (Fig. 14d). This tree was growing by $0.5 \mathrm{~mm} \mathrm{a}^{-1}$ on average during the first $60 \mathrm{a}$ when an abrupt decrease in growth rate (tree-ring width) to 0.05 $\mathrm{mm} \mathrm{a}^{-1}$ occurred (Figs $14 \mathrm{~d}$ and e). The dense rings in the outer part of this tree could indicate that it is of a similar age as the second sample (LuS 10802). The dates and the dendrochronological analyses of the tree logs not only suggest that the valley was forested and that Fláajökull was considerably smaller or absent at that time, but also that the glacier started to expand sometime after about 2100 $\mathrm{BP}$, possibly due to an abrupt climate deterioration.

\section{DISCUSSION}

\section{Drumlin formation}

In two sections located at the proximal end of drumlins, sections $A$ and $C$, glaciofluvial sediments make up $\sim 4 / 5$ of the section height and are overlain by subglacial traction till on top. Although our dataset lacks definitive indications of erosion in the form of erosional unconformities, this could suggest that the drumlins at Fláajökull are formed by a combination of erosion of pre-existing outwash sediments and deposition and shearing of till.

The glaciofluvial sediment in the drumlin cores suggests that the drumlins were formed around sticky spots in the substrate where higher resistance to basal sliding, erosion and deformation caused the deposition of the subglacial traction till (Boulton, 1987; Piotrowski and others, 2004; Stokes and others, 2007). Subsequently, the continuous flow of the glacier in this area between 1966 and 1995 shaped the till-draped sticky spots into drumlins. This corresponds to proposed mechanisms of drumlin formation at Breiðamerkurjökull (Evans and Twigg, 2002) and Skeiðarárjökull (Boulton, 1987; Waller and others, 2008), both southern outlets of the Vatnajökull ice cap, and suggests that the location and distribution of the drumlins is mainly controlled by the hydrological and sedimentological properties of the substrate, rather than for example, being related to crevasses (Alden, 1911; Johnson and others, 2010).

The drumlins at Fláajökull have a relatively low elongation ratio (1.4-4.8) and they all terminate abruptly at the 1995 moraine; however, there is no indication of erosion and truncation by meltwater at their distal end in front of the moraine. We suggest that the drumlins were formed 

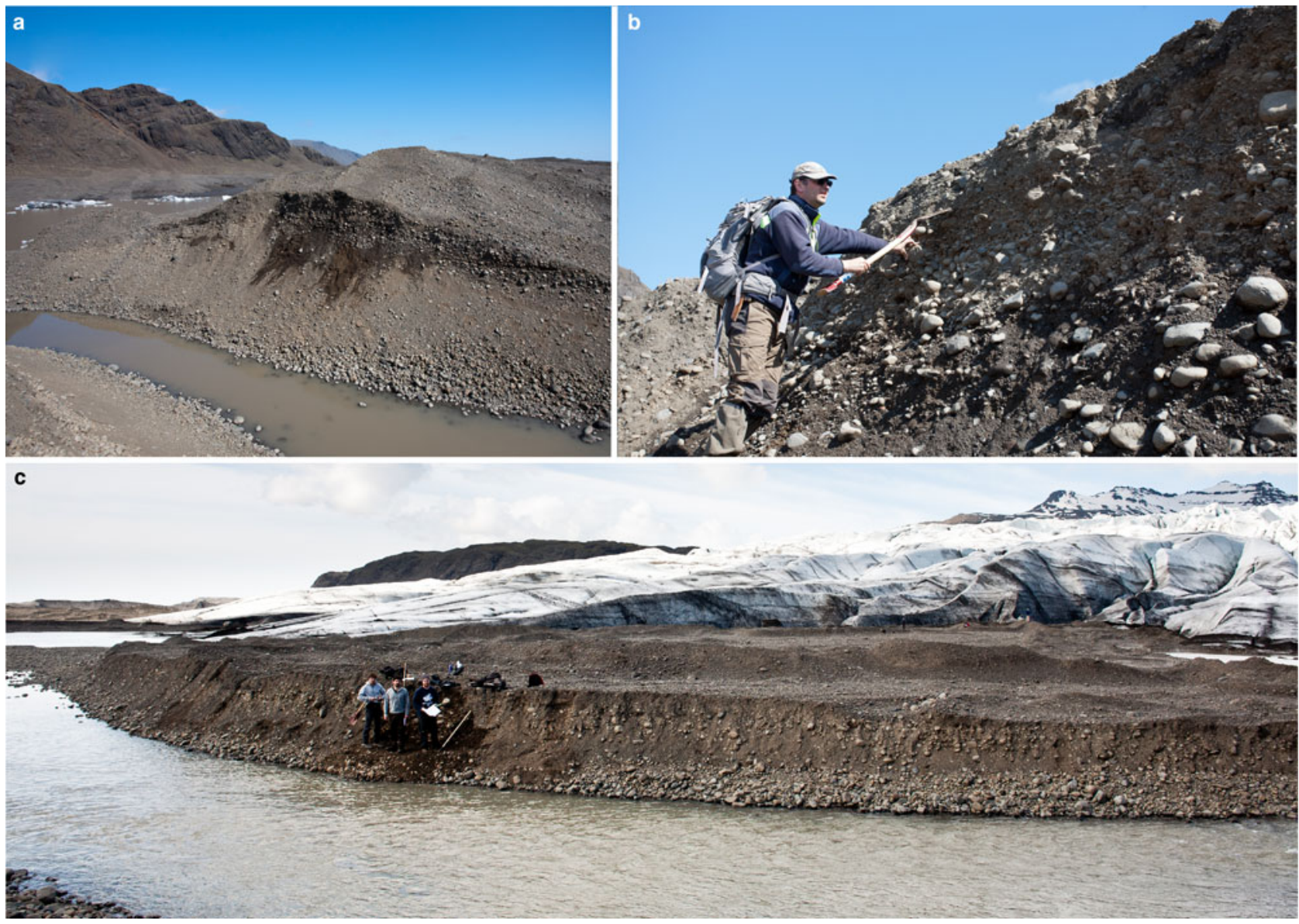

Fig. 9. (a) An overview of section B looking away from the glacier. The section is $\sim 8 \mathrm{~m}$ high. (b) Section $\mathrm{B}$, the spade is pointed at the contact between units B-1 and B-2. (c) An overview of section C.

sub-marginally during the 1966-1995 advance that terminated at this position; hence, they do not extend beyond it. It is worth stressing that this advance was not a surge but rather a response of the glacier to a continuously positive net mass balance over this period. It can thus also be concluded that the drumlins at Fláajökull were formed under 'normal' ice velocities like previously reported from for example, Sléttjökull and Sólheimajökull in Iceland (see Krüger and Thomsen, 1984; Krüger, 1987, 1994; Schomacker and others, 2012) rather than under

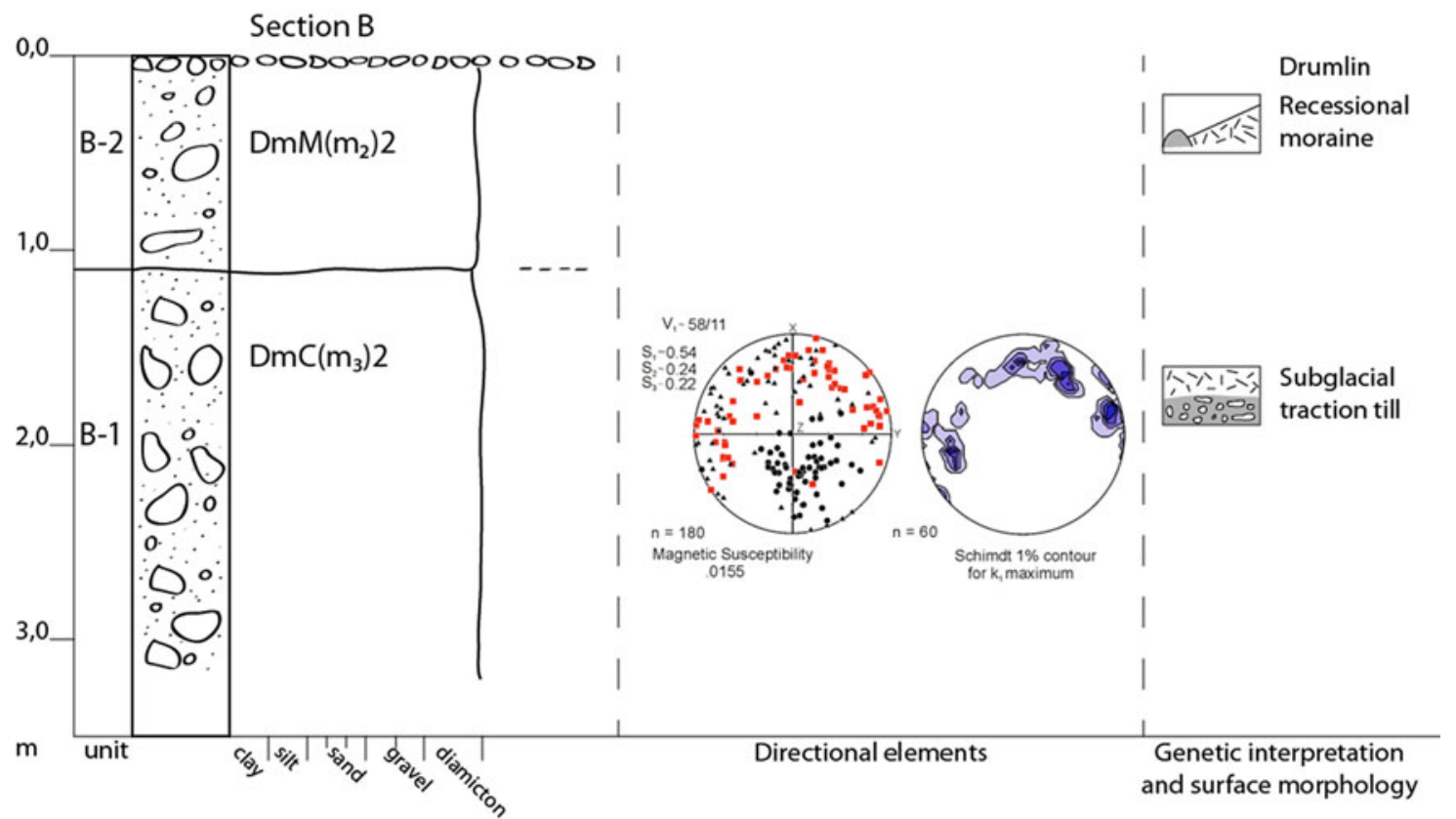

Fig. 10. Sedimentological log from section B. Explanations of symbols and lithofacies codes can be seen in Figure 8. 


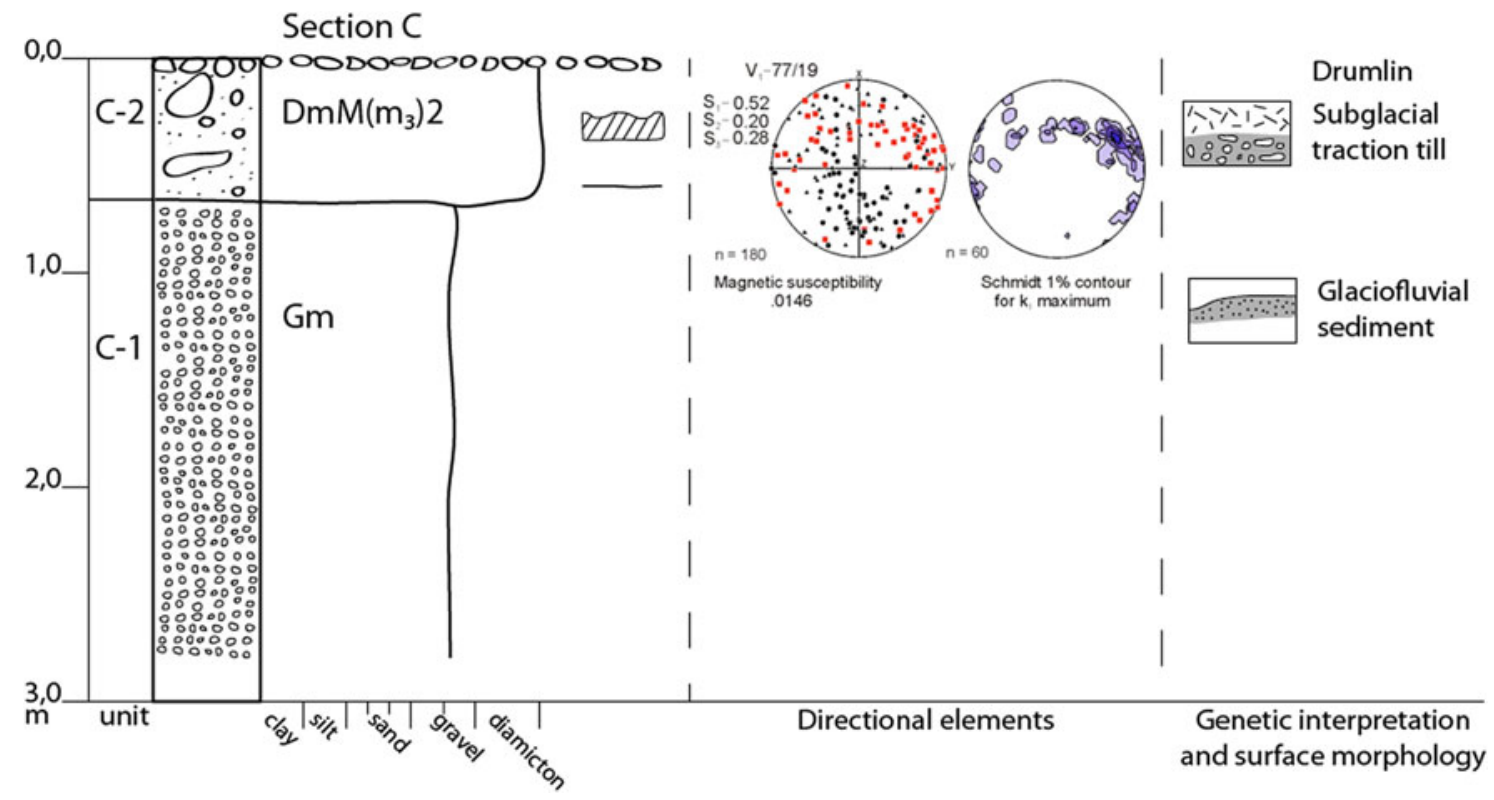

Fig. 11. Sedimentological log from section C. Explanations of symbols and lithofacies codes can be seen in Figure 8.
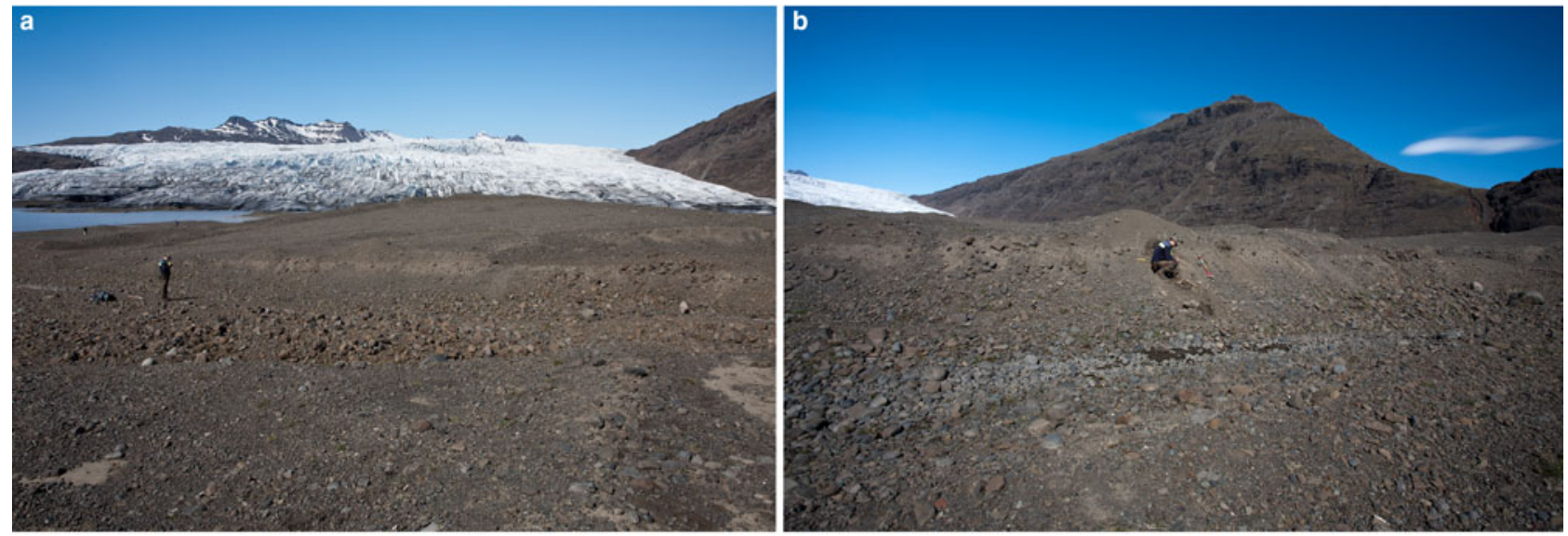

Fig. 12. (a) Overview of section D. The view is towards the glacier along the long axis of the drumlin. Person for scale by the section. (b) An overview of section D along the channel in which it occurs. Person for scale.

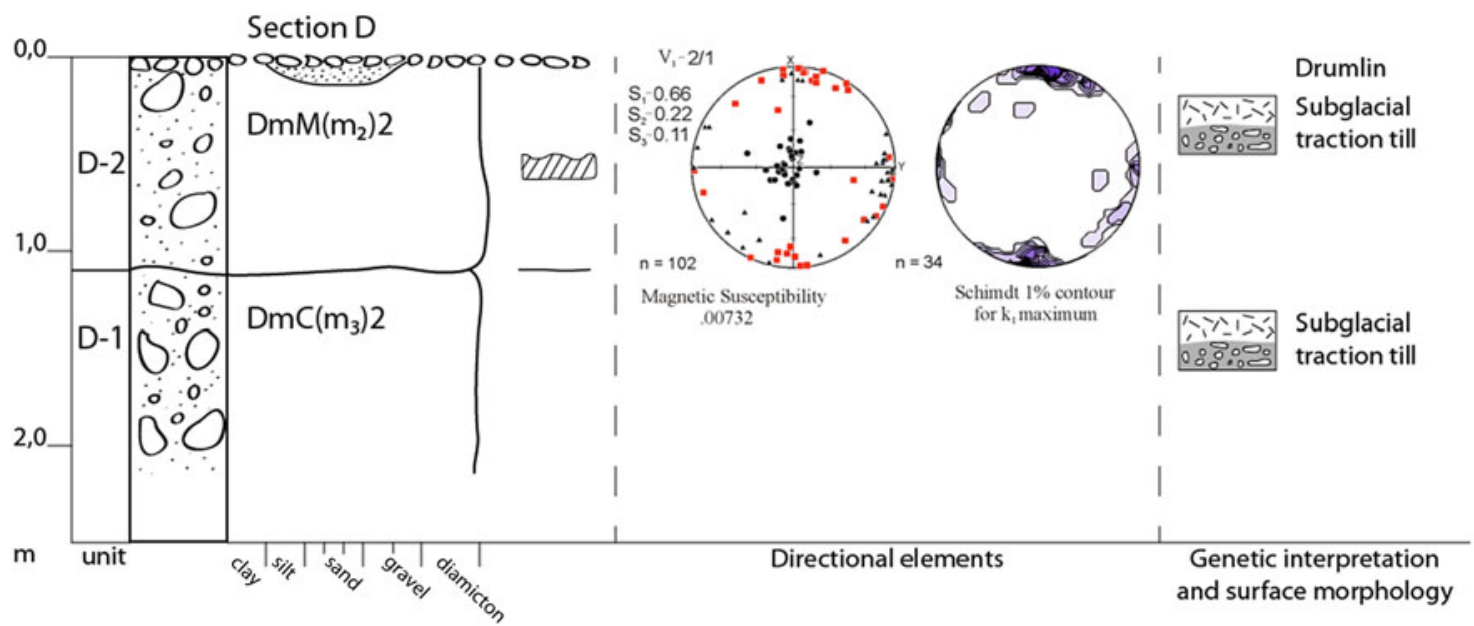

Fig. 13. Sedimentological log from section D. Explanations of symbols and lithofacies codes can be seen in Figure 8. 

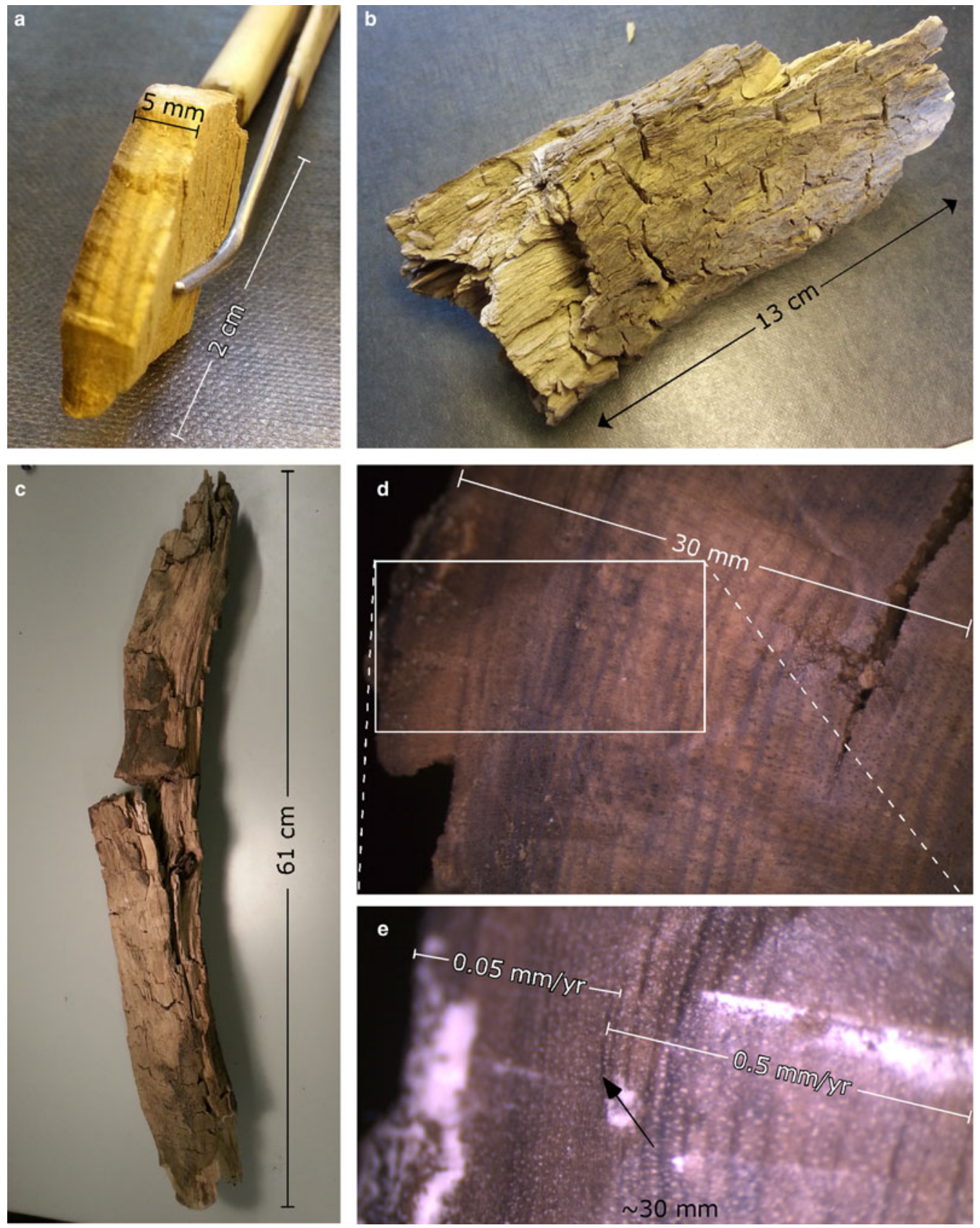

Fig. 14. (a) Sample LuS 10801 dated to 2310-2055 calendar year BP. The sample is the outermost part of a tree that was 20-30 $\mathrm{cm}$ in diameter, as indicated by the curvature of the sample. The width of the tree rings indicates relatively warm growing conditions and high growth rates. A pair of tweezers for scale. (b) Sample LuS 10802 dated to 2155-1990 calendar year BP. Dendrochronological analysis indicates a live span of 25-40 a and low growth rates (dense tree rings). (c) Sample IS000. This sample was not dated but analysed for dendrochronology. (d) and (e) Close-ups showing the tree rings of sample ISOOO with the growth rates indicated. The arrow points at the sharp boundary between higher and lower growth rates, which probably indicates an abrupt change in climate and growing conditions.

substantially enhanced velocities (ice streaming or surging), as has been suggested for highly elongate Pleistocene drumlins (e.g. Hart, 1999; Stokes and Clark, 1999, 2002; Briner, 2007; Hess and Briner, 2009) and for drumlins formed by surge-type glaciers in Iceland (e.g. Boulton, 1987; Hart, 1995; Waller and others, 2008; Johnson and others, 2010).

\section{Glaciation history}

The dates of the tree logs in the drumlins at Fláajökull of about 2100 years BP indicate that the valley now occupied by the glacier had been ice free and that the glacier started to reform at around that time. This correlates with the glacial history of Eyjabakkajökull, a surge-type outlet of the north-eastern part of the Vatnajökull ice cap, as reconstructed from sediment cores from Lake Lögurinn that receives meltwater from the glacial river draining Eyjabakkajökull. The results from Lögurinn indicate that Eyjabakkajökull did not exist from 9000 to 4400 years BP after which the glacier started to reform. The surges of Eyjabakkajökull started about 2200 years BP and the glacier continued to expand until about 1700 years BP when it reached a size it maintained until the onset of the LIA (Striberger and others, 2012). This is somewhat similar to the results of Geirsdóttir and others (2009), who suggest that the onset of the Neoglaciation in Iceland was sometime 
after 6000 years BP with increasing glacial activity between 4500 and 4000 years BP and even more between 3000 and $2500 \mathrm{BP}$, when temperatures were the lowest during the Holocene apart from the LIA. This is in line with chronological data from for example, Sólheimajökull (a southern outlet of the Mýrdalsjökull ice cap) and Kvíarjökull (at southern outlet of the Vatnajökull ice cap), which suggest that these glaciers had their maximum Late Holocene extent about 1800 and 3000 BP, respectively (Thorarinsson, 1956; Schomacker and others, 2012). The results from Fláajökull, therefore, contribute to a growing set of evidence from different locations in Iceland that outlet glaciers reformed in the late Holocene after having been absent or considerably smaller since the early Holocene, and that these fluctuations were driven by climate changes.

\section{CONCLUSIONS}

The forefield of Fláajökull contains 15 drumlins exposed during ice marginal retreat since 1995. The drumlins are 100-600 m long, 40-130 $\mathrm{m}$ wide and 5-10 $\mathrm{m}$ high, with an elongation ratio of (1.4-4.8).

The drumlins consist of glaciofluvial sediment in their cores and subglacial traction till on top. We suggest that glaciofluvial deposits acted as sticky spots onto which the subglacial traction till was deposited due to resistance to basal sliding, erosion and deformation.

The fact that the drumlins at Fláajökull occur just proximal to the 1995 end moraine and not beyond it indicates that, they were formed in a sub-marginal setting during a period of stillstand or minor re-advance from 1966 to 1995. If the drumlins were older, they would most likely have extended beyond the 1995 moraine.

The drumlins formed under 'normal' low-velocity ice flow conditions during the 1966-1995 re-advance and cannot be related to any kind of fast-flow events (e.g. a surge).

New datings of birch logs and the known age of the LIA terminal moraines suggest that the valley presently occupied by Fláajökull was ice free and carried a birch forest about 2100 cal. yr BP and that the glacier expanded thereafter to reach its maximum Holocene extent in 1894.

\section{ACKNOWLEDGEMENTS}

This study was funded by the University of Iceland Research Fund and the Icelandic Research Fund (RANNÍS) as part of our drumlin studies in Iceland. Anton Hansson at the Swedish National Laboratory for Wood Anatomy and Dendrochronology, Lund University, Sweden, is gratefully acknowledged for taking the photographs used in Figs 14d and e. We thank Richard Waller for a highly constructive review that significantly improved the manuscript. We also thank an anonymous reviewer and the scientific editor, Chris Stokes, for useful comments.

\section{REFERENCES}

Aðalgeirsdóttir G and 7 others (2011) Modelling the 20th and 21st century evolution of Hoffellsjökull glacier, SE-Vatnajökull, Iceland. Cryosphere, 5, 961-975 (doi: 10.5194/tc-5-961-2011)

Alden WC (1911) Radiation in glacial flow as a factor in drumlin formation. Geol. Soc. Am., Bull., 22, 733-734
Baltrūnas V, Waller RI, Kazakauskas V, Paškauskas S and Katinas V (2014) A comparative case study of subglacial bedforms in northern Lithuania and south-eastern Iceland. Baltica, 27, 75-92 (doi: 10.5200/baltica.2014.27.18)

Benn DI and Evans DJ (2006) Subglacial megafloods: outrageous hypothesis or just outrageous. In Glacier science and environmental change. Blackwell, London, 42-46

Björnsson H (2009) Jöklar á Íslandi. Forlagið, Reykjavik

Björnsson H and Pálsson F (2008) Icelandic glaciers. Jökull, 58, 365-386

Boulton G (1987) A theory of drumlin formation by subglacial sediment deformation. In Menzies J and Rose J eds. Drumlin Symposium. 25-80 A.A. Balkema, Rotterdam

Briner JP (2007) Supporting evidence from the New York drumlin field that elongate subglacial bedforms indicate fast ice flow. Boreas, 36, 143-147 (doi: 10.1111/j.1502-3885.2007.tb01188.x)

Burki V, Larsen E, Fredin O and Margreth A (2009) The formation of sawtooth moraine ridges in Bødalen, western Norway. Geomorphology, 105, 182-192 (doi: 10.1016/j.geomorph.2008.06.016)

Clark CD, Hughes ALC, Greenwood SL, Spagnolo M and Ng FSL (2009) Size and shape characteristics of drumlins, derived from a large sample, and associated scaling laws. Quat. Sci. Rev., 28, 677-692 (doi: 10.1016/j.quascirev.2008.08.035)

Evans D and Benn D (2004) A practical guide to the study of glacial sediments. Hodder Education, London

Evans DJ, Lemmen DS and Rea BR (1999) Glacial landsystems of the southwest Laurentide Ice Sheet: modern Icelandic analogues. J. Quat. Sci., 14, 673-691 (doi: 10.1002/(SICl)1099-1417 (199912)14:7<673::AID-JQS467>3.0.CO;2-\#)

Evans DJA and Twigg DR (2002) The active temperate glacial landsystem: a model based on Breiðamerkurjökull and Fjallsjökull, Iceland. Quat. Sci. Rev., 21, 2143-2177 (doi: 10.1016/S02773791(02)00019-7)

Evans DJA, Phillips ER, Hiemstra JF and Auton CA (2006) Subglacial till: formation, sedimentary characteristics and classification. Earth-Sci. Rev., 78, 115-176 (doi: 10.1016/j.earscirev. 2006.04.001)

Evans DJA, Ewertowski M and Orthon C (2015) Fláajökull (north lobe), Iceland: active temperate piedmont lobe glacial landsystem. J. Maps, 1-13 (doi: 10.1080/17445647.2015.1073185)

Geirsdóttir Á, Miller GH, Axford Y and Ólafsdóttir S (2009) Holocene and latest Pleistocene climate and glacier fluctuations in Iceland. Quat. Sci. Rev., 28, 2107-2118 (doi: 10.1016/j. quascirev.2009.03.013)

Hannesdóttir H, Björnsson H, Pálsson F, Aðalgeirsdóttir G and Guðmundsson S (2014) Variations of southeast Vatnajökull ice cap (Iceland) 1650-1900 and reconstruction of the glacier surface geometry at the Little Ice Age maximum. Geogr. Ann.: Ser. A, Phys. Geogr., 1-28 (doi: 10.1111/geoa.12064)

Hart JK (1995) Recent drumlins, flutes and lineations at VestariHagafellsjökull, Iceland. J. Glaciol., 41, 596-606

Hart JK (1999) Identifying fast ice flow from landform assemblages in the geological record: a discussion. Ann. Glaciol., 28, 59-66 (doi: 10.3189/172756499781821887)

Haselton GM (1966) Glacial geology of Muir Inlet, southeast Alaska. Ohio State University Institute of Polar Studies Report 18

Hess DP and Briner JP (2009) Geospatial analysis of controls on subglacial bedform morphometry in the New York Drumlin Field. Earth Surface Processes and Landforms, 34, 1126-1135

Jelínek V and Kropáček RV (1978) Statistical processing of anisotropy of magnetic susceptibility measured on groups of specimens. Studia geophysica et geodaetica, 22, 50-62 (doi: 10.1007/BF01613632)

Jóhannesson T and 7 others (2013) Ice-volume changes, bias estimation of mass-balance measurements and changes in subglacial lakes derived by lidar mapping of the surface of Icelandic glaciers. Ann. Glaciol., 54, 63-74 (doi: 10.3189/2013AoG63A422)

Johnson MD and 5 others (2010) Active drumlin field revealed the margin of Múlajökull, Iceland: a surge-type glacier. Geology, 38, 943-946 (doi: 10.1130/G31371.1) 
Jónsson SA, Schomacker A, Benediktsson ÍÖ, Ingólfsson Ó and Johnson MD (2014) The drumlin field and the geomorphology of the Múlajökull surge-type glacier, central Iceland. Ceomorphology, 207, 213-220 (doi: 10.1016/j.geomorph.2013.11.007)

Kerr M and Eyles N (2007) Origin of drumlins on the floor of Lake Ontario and in upper New York State. Sediment. Geol., 193, 7-20 (doi: 10.1016/j.sedgeo.2005.11.025)

Kjær KH, Krüger J and van der Meer JJM (2003) What causes till thickness to change over distance? Answers from Mýrdalsjökull, Iceland. Quat. Sci. Rev., 22, 1687-1700 (doi: 10.1016/S02773791(03)00162-8)

Krüger J (1987) Relationship of drumlin shape and distribution to drumlin stratigraphy and glacial history, Mýrdalsjökull, Iceland. In Menzies J and Rose J eds. Drumlin symposium. A.A. Balkema, Rotterdam, 257-266

Krüger J (1994) Glacial processes, sediments, landforms, and stratigraphy in the terminus region of Mýrdalsjökull, Iceland. Folia Geogr. Dan., 21, 1-233

Krüger J (1995) Origin, chronology and climatological significance of annual-moraine ridges at Mýrdalsjökull, Iceland. Holocene, 5, 420-427 (doi: 10.1177/095968369500500404)

Krüger J and Kjær KH (1999) A data chart for field description and genetic interpretation of glacial diamicts and associated sediments with examples from Greenland, Iceland, and Denmark. Boreas, 28, 386-402 (doi: 10.1111/j.1502-3885.1999.tb00228.x)

Krüger J and Thomsen $\mathrm{HH}$ (1984) Morphology, stratigraphy, and genesis of small drumlins in front of the glacier Mýrdalsjökull, South Iceland. J. Glaciol., 30, 94-105

Maclachlan JC and Eyles CH (2013) Quantitative geomorphological analysis of drumlins in the Peterborough drumlin field, Ontario, Canada. Geogr. Ann.: Ser. A, Phys. Geogr., 95, 125-144 (doi: 10.1111/geoa.12005)

Mark DM (1973) Analysis of axial orientation data, including till fabrics. Geol. Soc. Am. Bull., 84, 1369-1374 (doi: 10.1130/ 0016-7606(1973)84<1369:AOAODI > 2.0.CO;2)

Menzies J (1979) A review of the literature on the formation and location of drumlins. Earth-Sci. Rev., 14, 315-359 (doi: 10.1016/0012-8252(79)90093-X)

Pálsson F and Björnsson H (2000) Vatnsrennsli undan eystri hluta Fláajökuls. Raunvísindastofnun Háskólans, Reykjavik

Patterson CJ and Hooke RL (1995) Physical environment of drumlin formation. J. Glaciol., 41, 30-38

Piotrowski JA, Larsen NK and Junge FW (2004) Reflections of soft glacial beds as a mosaic of deformating and stable spots. Quat. Sci. Rev., 23, 993-1000 (doi: 10.1016/j.quascirev.2004. 01.006)
Rabassa J (1987) Drumlins and drumlinoid forms in northern James Ross Island, Antarctic Peninsula. In Menzies J ed. Drumlin symposium. 267-288 Balkema, Rotterdam

Reimer RJ and 29 others (2013) Intcal13 and marine13 radiocarbon age calibration curves $0-50,000$ years cal BP. Radiocarbon, 55, 1869-1887 (doi: 10.2458/azu_js_rc.55.16947)

Schomacker A, Krüger J and Kjær KH (2006) Ice-cored drumlins at the surge-type glacier Brúarjökull, Iceland: a transitional-state landform. J. Quat. Sci., 21, 85-93 (doi: 10.1002/jqs.949)

Schomacker A and 6 others (2012) Late Holocene and modern glacier changes in the marginal zone of Sólheimajökull, South Iceland. Jökull, 62, 111-130

Sigurdsson O (2003) Jöklabreytingar 1930-1960, 1960-1990 og 2001-2002. Jökull, 53, 55-62

Sigurdsson O (2013) Jöklabreytingar 1930-1970, 1970-1995, 1995-2011 og 2011-2012. Jökull, 63, 118-122

Slomka JM and Eyles CH (2015) Architectural-landsystem analysis of a modern glacial landscape, Sólheimajökull, southern Iceland. Geomorphology, 230, 75-97 (doi: 10.1016/j. geomorph.2014.11.006)

Stokes CR and Clark CD (1999) Geomorphological criteria for identifying Pleistocene ice streams. Ann. Glaciol., 28, 67-74

Stokes CR and Clark CD (2001) Palaeo-ice streams. Quat. Sci. Rev., 20, 1437-1457 (doi: 10.1016/S0277-3791(01)00003-8)

Stokes CR and Clark CD (2002) Are long subglacial bedforms indicative of fast ice flow? Boreas, 31, 239-249

Stokes CR, Clark CD, Lian OB and Tulaczyk S (2007) Ice stream sticky spots: a review of their identification and influence beneath contemporary and palaeo-ice streams. Earth-Sci. Rev., 81, 217-249 (doi: 10.1016/j.earscirev.2007.01.002)

Striberger J, Björck S, Holmgren S and Hamerlík L (2012) The sediments of Lake Lögurinn-a unique proxy record of Holocene glacial meltwater variability in eastern Iceland. Quat. Sci. Rev., 38, 76-88 (doi: 10.1016/j.quascirev.2012.02.001)

Thorarinsson S (1956) On variations of Svínafellsjökull, Skaftafellsjökull and Kvíárjökull. Jökull, 6, 1-15

van der Meer J (1983) A recent drumlin with fluted surface in the Swiss Alps, Evenson, EB, Schluchter, Ch. \& Rabassa, J., Till and related deposits. In Proceeding of the INQUA Symposia on the Genesis and Lithology of Quaternary Deposits/USA 1981/ Argentina1982, 105-109

Waller RI, van Dijk TAGP and Knudsen Ó (2008) Subglacial bedforms and conditions associated with the 1991 surge of Skeiðarárjökull, Iceland. Boreas, 37, 179-194 (doi: 10.1111/j. 1502-3885.2007.00017.x) 